\title{
Przesiewowe badania słuchu i mowy uczniów szkoły muzycznej w wieku wczesnoszkolnym
}

\section{The screening of the hearing and speech of the students of music school at early school-age}

\author{
Przemysław Płoszczak ${ }^{1,2}$, Anita Lorenc ${ }^{1}$ \\ ${ }^{1}$ Uniwersytet Marii Curie-Skłodowskiej, Zakład Logopedii i Językoznawstwa Stosowanego, Lublin \\ ${ }^{2}$ Społeczna Terapeutyczna Szkoła Podstawowa im. H. Ch. Andersena, Lublin
}

Adres autora: Przemysław Płoszczak, Społeczna Terapeutyczna Szkoła Podstawowa im. H. Ch. Andersena, ul. Przyjaźni 20, 20-314 Lublin, e-mail: p.ploszczak@gmail.com

\section{Streszczenie}

Cel: Celem artykułu jest prezentacja wyników przesiewowych badań słuchu i mowy dzieci w wieku wczesnoszkolnym uczęszczających do szkoły muzycznej.

\begin{abstract}
Metoda: U dzieci, które uzyskały nieprawidłowy wynik w przesiewowym badaniu słuchu, przeprowadzono dodatkowo badanie audiometryczne, na podstawie którego obliczono średni ubytek słuchu dla każdego ucha osobno. Określono również, czy poziom odpowiadający najsłabszej reakcji na audiogramie pokrywa się z wadą wymowy głoski lub grup głosek posiadających swe cechy akustyczne w zbliżonym zakresie częstotliwości.

Wyniki: Uzyskane wyniki pozwoliły skorelować zdiagnozowaną wadę wymowy z przyczyną, jaką mógł być minimalny niedosłuch. Warto podkreślić, że żadna z przebadanych osób nie osiągnęła średniego wyniku w granicach $21 \mathrm{~dB}$, pozwalającego zdiagnozować lekki ubytek słuchu wg Międzynarodowego Biura Audiofonologii. Pojawił się więc finalnie problem tzw. przypadków granicznych, czyli osób skazanych na brak jakiejkolwiek opieki terapeutycznej ze względu na zaszeregowanie ich do grupy z całkowicie sprawnym słuchem.
\end{abstract}

Słowa kluczowe: badania przesiewowe słuchu i mowy • systemy „Mówię...” oraz „Słyszę...” • audiometria tonalna • przypadki graniczne

\section{Abstract}

Aim: The main goal of the article is the presentation of the outcome of the screening conducted for the children at the early school-age attending the music school.

Method: For the negative results of the screening, the pure tone audiometry was made, on the basis of which there was an average hearing loss counted for each ear separately. The study also specifies if the weakest reaction place on an audiogram overlaps the speech disability of a sound or a group of sounds that have the acoustic features of the same frequency range.

Results: The results of the study enabled to correlate the diagnosed speech disability with the cause, which may have been the light amblyacousia. It is worth highlighting that none of the screened people reached the outcome surrounding $21 \mathrm{~dB}$ that enables the diagnosis of the light hearing loss according to BIAP (Bureau International d'Audiophonologie). This led to a problem of so called borderline cases, which means people that lack the therapy because they were earlier qualified to a hearingabled group.

Key words: the screening of the speech and hearing • "I can speak..." and "I can hear..." systems • pure tone audiometry (PTA) • borderline cases 


\section{Wstęp}

Punktem wyjścia do rozważań zawartych w niniejszym artykule były przesiewowe badania słuchu i mowy u dzieci w młodszym wieku szkolnym. Podstawową motywacją do przeprowadzenia testów przesiewowych była weryfikacja dostępnych w literaturze wyników statystycznych, dotyczących po pierwsze: uszkodzeń słuchu w populacji uczniów w wieku 7-9 lat (badania epidemiologiczne przeprowadzone przez Instytut Fizjologii i Patologii Słuchu wskazują, że co piąte dziecko w wieku 6-19 lat ma problemy ze słuchem); po drugie, wpływu, jaki wywierają na rozwój fonologiczny dziecka i jego wymowę w pierwszych latach edukacji wczesnoszkolnej. Jednym z najważniejszych pytań, jakie pojawiły się w trakcie badań, było: czy istnieje korelacja pomiędzy dodatnim wynikiem badania przesiewowego słuchu (który sugeruje istnienie zaburzenia słuchu) i takim samym rezultatem badania przesiewowego mowy. Zainteresowanie zwiększał fakt, że na miejsce badań wybrano szkołę muzyczną, w której przynajmniej teoretycznie powinny kształcić się dzieci niemające żadnych problemów ze słuchem.

U wszystkich dzieci z dodatnim wynikiem badania przesiewowego słuchu wykonano audiometrię tonalną. Obliczono dzięki temu średni ubytek słuchu dla każdego ucha osobno oraz określono, czy najsłabiej odbierane częstotliwości pokrywają się z cechami akustycznymi głosek wadliwie wymawianych przez dzieci.

W niniejszym artykule zawarto opis przedmiotu i celu badań, charakterystykę terenu badań i grupy badanej. Scharakteryzowano ponadto metody, techniki oraz narzędzia badawcze, kończąc opisem organizacji badań. Finalnie przeprowadzono analizę i interpretację otrzymanych wyników. Czytelnik znajdzie odpowiedź na postawione pytania badawcze oraz próbę określenia głównych przyczyn zaobserwowanych problemów.

\section{Przedmiot i cel badań}

Badania przesiewowe ${ }^{1}$ służą szybkiemu wyselekcjonowaniu dzieci z różnorodnymi zaburzeniami, w omawianym przypadku testy przesiewowe dotyczyły badania mowy i słuchu. Przedmiotem badań było wyselekcjonowanie dzieci w młodszym wieku szkolnym pod względem zaburzeń artykulacji oraz percepcji słuchowej. Ze względu na podjęty przedmiot badań zarysowały się następujące cele: po pierwsze - określenie liczby dzieci w trzech klasach szkoły podstawowej mających wady wymowy, po drugie - określenie tych wad, sklasyfikowanie i porównanie $\mathrm{z}$ aktualnym stanem badań statystycznych w tym zakresie, po trzecie - określenie liczby dzieci mających ubytki słuchu, po czwarte - weryfikacja zależności pomiędzy wadą wymowy a ubytkiem słuchu w badanej populacji.

Przyjęte cele ukierunkowały treść poniższych pytań badawczych:

1. Jaki odsetek uczniów pierwszej klasy szkoły podstawowej posiada wady wymowy?
2. Jakie są to wady oraz które wady dominują?

3. Czy w dwóch wyższych klasach nauczania wczesnoszkolnego widoczne jest zmniejszenie odsetka dzieci z wadami wymowy i jakie są to odchylenia?

4. Jaki procent uczniów badanej grupy uzyska wynik dodatni w przesiewowym badaniu słuchu?

5. Czy w dwóch wyższych klasach nauczania wczesnoszkolnego widoczne jest zmniejszenie odsetka dzieci $\mathrm{z}$ dodatnim wynikiem tego badania?

6. Czy istnieje zależność pomiędzy wadami wymowy a ubytkami słuchu w badanej populacji?

\section{Charakterystyka terenu badań i badanej grupy}

Badania przeprowadzone zostały w Ogólnokształcącej Szkole Muzycznej I stopnia w Przemyślu. Sekcja nauczania wczesnoszkolnego składa się z pięciu klas:

- klasa I a, 17 osób;

- klasa I b, 17 osób;

- klasa II, 27 osób;

- klasa III a, 14 osób;

- klasa III b, 15 osób.

Badaniami objęto łącznie 77 dzieci z klas I-III. Grupę badawczą stanowiły dzieci w przedziale wiekowym 7-9 lat, uczące się w pięciu klasach. Badana grupa obejmowała łącznie 26 chłopców i 51 dziewczynek. Rozkład badanej grupy przedstawia Tabela 1.

Tabela 1. Rozkład badanej grupy

\begin{tabular}{|c|c|c|c|}
\hline \multirow{2}{*}{ Klasa } & \multirow{2}{*}{$\begin{array}{l}\text { Liczba } \\
\text { badanych }\end{array}$} & \multicolumn{2}{|c|}{ Płeć } \\
\hline & & Chłopcy & Dziewczynki \\
\hline I a & 14 & 3 & 11 \\
\hline $\mathrm{Ib}$ & 14 & 4 & 10 \\
\hline II & 24 & 7 & 17 \\
\hline III a & 12 & 6 & 6 \\
\hline III b & 13 & 6 & 7 \\
\hline Ogółem & 77 & 26 & 51 \\
\hline
\end{tabular}

\section{Techniki i narzędzia badawcze}

W celu udzielenia odpowiedzi na postawione pytania posłużono się dwiema metodami badawczymi, którym przyporządkowane zostały odpowiadające im techniki i narzędzia, określające sposób postępowania oraz umożliwiające rzetelne zebranie materiału badawczego.

Pierwszą metodą badawczą było zastosowanie multimedialnych testów przesiewowych „Mówię...” oraz „Słyszę...” [zob. Skarżyński, Czyżewski, Senderski, 2001]. Jest to seria programów komputerowych przeznaczonych do badania słuchu i mowy przede wszystkim u dzieci i młodzieży.

\footnotetext{
1. Por. testy przesiewowe dostępne na polskim rynku wydawniczym, tj.: Z. Tarkowski (1992) Przesiewowy test logopedyczny, Lublin; D. Emiluta-Rozya, H. Mierzejewska, P. Atys (1995) Badania przesiewowe do wykrywania zaburzeń rozwoju mowy u dzieci dwu-, cztero- i sześcioletnich, Warszawa; S. Grabias, Z. M. Kurkowski, T. Woźniak (2002) Logopedyczny test przesiewowy dla dzieci w wieku szkolnym, Lublin.
} 
Drugą metodą badawczą było zastosowanie audiometrii tonalnej, która jest podstawową metodą subiektywnego badania słuchu. Służy ona wyznaczeniu progu słyszenia, dzięki czemu można określić rodzaj oraz stopień ubytku słuchu. W klasycznym badaniu wynik - średni ubytek słuchu - podany w decybelach otrzymywany jest poprzez dodanie do siebie wartości z trzech progów: $500 \mathrm{~Hz}, 1000 \mathrm{~Hz}$ i $2000 \mathrm{~Hz}$ i podzielenie otrzymanych wartości przez trzy. W przypadku analizowanych poniżej badań, audiometria tonalna wykonywana była metodą zstępującą począwszy od częstotliwości $1000 \mathrm{~Hz}$ i przez 2, 4 i $8 \mathrm{kHz}$, kończąc na częstotliwościach $250 \mathrm{~Hz}$ i $500 \mathrm{~Hz}$, umożliwiając wyznaczenie progu słyszenia dla tych częstotliwości.

\section{Organizacja badań}

Badania przeprowadzone zostały w lutym oraz marcu 2010 roku. Zakres badań obejmował dwa etapy. Pierwszy z nich polegał na przeprowadzeniu testów przesiewowych słuchu i mowy w grupie 77 dzieci z klas I-III. Badania trwały cztery kolejne dni w godzinach od ósmej do czternastej, co dawało możliwość przebadania dziennie około dwudziestu dzieci. Dane zapisywano bezpośrednio w trakcie rozwiązywania zadań. Podczas tego etapu uzyskano także dostęp do kart zdrowia dzieci, jednak tylko w dwóch wypadkach odnaleziono wpis dotyczący wady wymowy, z oczywistych zaś przyczyn nie mogło być mowy o jakiejkolwiek adnotacji dotyczącej problemów ze słuchem (szkoła muzyczna).

Drugi etap obejmował badanie audiometryczne. Wyselekcjonowano dwadzieścioro dzieci mających dodatni wynik w obu przeprowadzonych testach, bądź tylko w teście „Słyszę...". Badania wykonano w odpowiednich warunkach akustycznych, w specjalnie przygotowanym, wytłumionym pomieszczeniu, zapewniającym ciszę i spokój, umożliwiając dziecku koncentrację przy udzielaniu odpowiedzi. Indywidualne badanie trwało przeciętne 10-14 minut. Na każdym etapie testy przebiegały bez zakłóceń, które mogłyby rzutować na jakość zebranego materiału.

\section{Charakterystyka wyników uzyskanych w teście przesiewowym mowy}

Dla przejrzystości niniejszego opracowania warto przypomnieć, że test przesiewowy mowy składał się z pięciu zadań:

a) oceny słuchu fonematycznego,

b) oceny motoryki narządów mowy,

c) oceny artykulacji,

d) oceny słownictwa,

e) oceny gramatyki.

W związku z tym, że nie zaobserwowano większych odchyleń przy ocenie słownictwa i gramatyki, a w ocenie słuchu fonematycznego wszystkie dzieci wypadły poprawnie, zaś w ocenie motoryki narządów mowy potwierdziły się w zasadzie trudności wpływające na wady wymowy, biorąc pod uwagę ogólny charakter testu przesiewowego, który to zgodnie ze swoją specyfiką pomaga wychwycić osoby z problemami, skupiono się na ocenie artykulacji. Traktuje o tym Tabela 2 wskazująca na ogólny odsetek dzieci (22\%), które posiadają wady wymowy, na tle ogólnej liczby przebadanych dzieci. Zestawiając ten wynik (przypominając jednocześnie, że dotyczy on wad wymowy u dzieci 7-9-letnich) z badaniami autorów zajmujących się tą tematyką na przestrzeni ostatnich kilkudziesięciu lat [por. Jastrzębowska, 2003], można stwierdzić, że potwierdziły się pewne tendencje wykazujące zgodność z uzyskanymi w latach wcześniejszych wynikami.

Tabela 2. Ogólna liczba dzieci z dodatnim wynikiem testu „Mówię...”(wadami wymowy)

\begin{tabular}{ccc}
\hline $\mathbf{N}$ & $\begin{array}{c}\text { Liczba badanych dzieci } \\
\text { z dodatnim wynikiem testu } \\
\text { „Mówię" / z wadami wymowy }\end{array}$ & $\begin{array}{c}\text { Procent } \\
\text { badanych } \\
\text { dzieci }\end{array}$ \\
\hline 77 & 17 & $22,08 \%$ \\
\hline
\end{tabular}

Nieodzowna jest w tym miejscu konstatacja, że niezbędne było uzupełnienie danych pochodzących $\mathrm{z}$ testu przesiewowego w postaci notatek służących skatalogowaniu wad wymowy. W innym bowiem przypadku, choć główny temat pracy byłby zrealizowany, wyniki przedstawiałyby bardzo duży poziom ogólności, w zasadzie mogłyby kończyć się na zasygnalizowaniu problemu i wskazaniu potrzeby kontaktu z logopedą. Tak więc, pomimo tego, że nie rejestrowano materiału dźwiękowego, możliwe było sklasyfikowanie poszczególnych wad wymowy. Z Tabeli 3 wynika, że nieco ponad $2 / 5$ dzieci z nieprawidłowym wynikiem testu „Mówię...” niepoprawnie realizuje /r/, prawie 1/4 niepoprawnie realizuje /r/ oraz wszystkie lub wybrane spółgłoski sybilantne, tyle samo - niespełna $1 / 4$ analizowanej grupy miało problem wyłącznie ze spółgłoskami sybilantnymi, zaś niespełna $12 \%$ dzieci zaprezentowało mowę bezdźwięczną.

Tabela 3. Rodzaje wad wymowy występujące w badanej grupie

\begin{tabular}{lccc}
\hline $\mathbf{N}$ & $\begin{array}{c}\text { Rodzaje wad wymowy } \\
\mathbf{u} \text { badanych dzieci }\end{array}$ & $\begin{array}{c}\text { Liczba } \\
\text { badanych } \\
\text { dzieci }\end{array}$ & $\begin{array}{c}\text { Procent } \\
\text { badanych } \\
\text { dzieci }\end{array}$ \\
\hline 17 1. Rotacyzm & 7 & $41,18 \%$ \\
\hline 2. Rotacyzm i sygmatyzm & 4 & $23,53 \%$ \\
\hline 3. Sygmatyzm & 4 & $23,53 \%$ \\
\hline 4. Mowa bezdźwięczna & 2 & $11,76 \%$ \\
\hline
\end{tabular}

Wyniki prezentowałyby się inaczej pod względem statystycznym, gdyby zrezygnowano $\mathrm{z}$ ujęcia w jednej grupie osób z rotacyzmem i sygmatyzmem, szeregując wady tylko do trzech grup. Nie uczyniono tego, bowiem osoby mające więcej niż jedną wadę wymowy musiałyby się zdublować w dwóch grupach, przez co wynik ogółu zostałby wypaczony, a liczba osób z wadami zwiększyłaby się z 17 do 21 . Wówczas statystyka przedstawiałaby się następująco: rotacyzm 52,85\%; sygmatyzm 38,09\%; mowa bezdźwięczna 9,52\%.

Zrezygnowano $\mathrm{w}$ tym miejscu $\mathrm{z}$ porównania $\mathrm{z}$ badaniami dostępnymi w literaturze, nie prowadzono bowiem w zasadzie miarodajnych statystyk obejmujących tak dużą rozpiętość wiekową, jak charakteryzowane w tym miejscu dzieci 7-9-letnie. Odniesienie statystyczne przydatne będzie w kolejnych punktach analizy skupiającej się na podsumowaniu wyników w stosunku do poszczególnych klas. Warto 
jednak wskazać na zaskakująco wysoką przewagę rotacyzmu nad sygmatyzmem, sięgającą ponad 15\%.

\section{Szczegółowa analiza wyników uzyskanych w klasach I-III}

W dwóch klasach pierwszych przebadano łącznie 28 dzieci, z których 10 ma wadę wymowy (Tabela 4). Stanowi to nieco ponad 1/3 ogółu badanych siedmiolatków.

Tabela 4. Ogólna liczba dzieci z wadami wymowy w klasach I

\begin{tabular}{ccc}
\hline $\mathbf{N}$ & $\begin{array}{c}\text { Liczba badanych dzieci } \\
\text { z wadami wymowy }\end{array}$ & $\begin{array}{c}\text { Procent badanych } \\
\text { dzieci }\end{array}$ \\
\hline 28 & 10 & $35,71 \%$ \\
\hline
\end{tabular}

Rozkład wad wymowy przedstawia się następująco:

Tabela 5. Rodzaje wad wymowy występujące u dzieci z klas I

\begin{tabular}{lccc}
\hline $\mathbf{N}$ & $\begin{array}{c}\text { Rodzaje wad wymowy } \\
\text { u badanych dzieci }\end{array}$ & $\begin{array}{c}\text { Liczba } \\
\text { badanych } \\
\text { dzieci }\end{array}$ & $\begin{array}{c}\text { Procent } \\
\text { badanych } \\
\text { dzieci }\end{array}$ \\
\hline 10 & 3 & $30,00 \%$ \\
\hline 1. Rotacyzm & 3 & $30,00 \%$ \\
\hline 2. Rotacyzm i sygmatyzm & 3 & $30,00 \%$ \\
\hline 3. Sygmatyzm & 1 & $10,00 \%$ \\
\hline 4. Mowa bezdźwięczna & & \\
\hline
\end{tabular}

Problem $\mathrm{z}$ realizacją / $\mathrm{r} /$ prezentuje prawie $1 / 3$ badanych. Analogiczna liczba dzieci ma nieprawidłową wymowę spółgłosek sybilantnych. Mowę bezdźwięczną zaobserwowano u jednej osoby. Uwagę zwraca grupa osób mających więcej niż jedną wadę wymowy (również niemal 1/3), w tym i każdym następnym przypadku w niniejszej pracy będzie to połączenie rotacyzmu $\mathrm{z}$ sygmatyzmem. Nie można przy tym odnieść się w sposób jednoznaczny do porównywania $z$ innymi badaniami, np. G. Jastrzębowska przeprowadziła bowiem swoje badania w 1993 roku na grupie 575 dzieci 6-7-letnich. Autorka ta uzyskała następujące wyniki: 42,3\% badanych - sygmatyzm, 13,6\% rotacyzm, 4,8\% - mowa bezdźwięczna. Jednakże zarówno rozbieżność pomiędzy liczbą przebadanych osób, jak i rodzaj przeprowadzonego testu nie pozwalają na bezpośrednie porównanie, stanowić mogą jedynie pewien element wzbogacający prowadzoną analizę.

W klasie drugiej przebadano 24 dzieci, z których 6 ma wadę wymowy (por. Tabela 6). Stanowi to $1 / 4$ spośród ogółu badanych ośmiolatków.

Tabela 6. Ogólna liczba dzieci z wadami wymowy w klasie II

\begin{tabular}{ccc}
\hline N & $\begin{array}{c}\text { Liczba badanych dzieci } \\
\text { z wadami wymowy }\end{array}$ & $\begin{array}{c}\text { Procent badanych } \\
\text { dzieci }\end{array}$ \\
\hline 24 & 6 & $25,00 \%$ \\
\hline
\end{tabular}

W porównaniu z odsetkiem osób klasy pierwszej zauważalny jest spadek liczby dzieci z wadami wymowy (z prawie $36 \%$ do $25 \%$ ). Rozkład wad wymowy przedstawia się następująco:

Tabela 7. Rodzaje wad wymowy występujące u dzieci z klasy II

\begin{tabular}{llcc}
\hline $\mathbf{N}$ & $\begin{array}{c}\text { Rodzaje wad wymowy } \\
\mathbf{u} \text { badanych dzieci }\end{array}$ & $\begin{array}{c}\text { Liczba } \\
\text { badanych } \\
\text { dzieci }\end{array}$ & $\begin{array}{c}\text { Procent } \\
\text { badanych } \\
\text { dzieci }\end{array}$ \\
\hline 6 & 3 & $50,00 \%$ \\
\hline 1. Rotacyzm & 1 & $16,67 \%$ \\
\hline 2. Rotacyzm i sygmatyzm & 1 & $16,67 \%$ \\
\hline 3. Sygmatyzm & 1 & $16,67 \%$ \\
\hline 4. Mowa bezdźwięczna & & \\
\hline
\end{tabular}

Tu także przeważa nieprawidłowa realizacja /r/, co stanowi dokładnie połowę wszystkich osób $\mathrm{z}$ wadami wymowy w tej klasie. Ponadto sygmatyzm i mowę bezdźwięczną wykryto u dwóch osób, zaś u jednej osoby występuje więcej niż jedna wada wymowy.

W dwóch klasach trzecich przebadano 25 dzieci, tylko u jednego dziecka stwierdzono wadę wymowy - rotacyzm. Można więc mówić o bardzo znacznym spadku procentowym w stosunku do wad wymowy u dzieci siedmioi ośmioletnich: z prawie $36 \% \mathrm{w}$ klasie pierwszej do jedynie $4 \%$ w klasie trzeciej.

Tabela 8. Ogólna liczba dzieci z wadami wymowy w klasach III

\begin{tabular}{ccc}
\hline $\mathbf{N}$ & $\begin{array}{c}\text { Liczba badanych dzieci } \\
\text { z wadami wymowy }\end{array}$ & $\begin{array}{c}\text { Procent } \\
\text { badanych } \\
\text { dzieci }\end{array}$ \\
\hline 25 & 1 & $4,00 \%$ \\
\hline
\end{tabular}

Wyniki ogółem przedstawiają się następująco:

Tabela 9. Zestawienie porównawcze liczby dzieci z wadami wymowy w poszczególnych przedziałach wiekowych

\begin{tabular}{cccc}
\hline Klasa & $\begin{array}{c}\text { Liczba } \\
\text { badanych } \\
\text { ogótem }\end{array}$ & $\begin{array}{c}\text { Liczba badanych } \\
\text { dzieci } \\
\text { z wadami } \\
\text { wymowy }\end{array}$ & $\begin{array}{c}\text { Procent } \\
\text { badanych } \\
\text { dzieci }\end{array}$ \\
\hline Klasa I & 28 & 10 & $35,71 \%$ \\
\hline Klasa II & 24 & 6 & $25,00 \%$ \\
\hline Klasa III & 25 & 1 & $4,00 \%$ \\
\hline
\end{tabular}

Charakterystyka wyników uzyskanych w teście przesiewowym słuchu

Test przesiewowy słuchu składał się z dwóch części:

- audiometrycznego testu tonalnego,

- badania rozumienia mowy w szumie. 
W związku z tym, że wszystkie badane dzieci osiągnęly w teście rozumienia mowy w szumie wynik w granicach normy, tj. prawidłowe zrozumienie $90 \%$ i więcej prezentowanych słów [zob. Skarżyński, Czyżewski, Senderski, 2001], skupiono się na analizie audiometrycznego testu tonalnego, utożsamiając jego dodatni wynik z dodatnim wskazaniem całego testu „Słyszę...”. Tak więc, jak wskazuje Tabela 10, na 77 przebadanych dzieci ponad 1/4 uzyskała wynik niezadawalający.

Tabela 10. Ogólna liczba dzieci z dodatnim wynikiem testu „Słyszę...”, wśród których przeprowadzono audiometrię tonalną

\begin{tabular}{ccc}
\hline N & $\begin{array}{c}\text { Liczba badanych dzieci } \\
\text { dodatnim wynikiem testu } \\
\text {,Styszę...”, wśród których } \\
\text { przeprowadzono audiometrię } \\
\text { tonalną (PTA) }\end{array}$ & $\begin{array}{c}\text { Procent } \\
\text { badanych } \\
\text { dzieci }\end{array}$ \\
\hline 77 & 20 & $25,97 \%$ \\
\hline
\end{tabular}

Po podzieleniu tej grupy na dzieci, które uzyskały dodatni wynik w teście przesiewowym „Mówię...”, oraz te z wynikiem zadawalającym, uzyskano interesujący wskaźnik informujący o tym, że niemal połowa badanych $\mathrm{z}$ dodatnim wynikiem badania przesiewowego mowy to osoby, które uzyskały dodatni wynik w badaniu przesiewowym słuchu.

Tabela 11. Liczba dzieci z wadami wymowy oraz dodatnim wynikiem testu „Styszę...”

\begin{tabular}{ccc}
\hline Liczba badanych dzieci & $\begin{array}{c}\text { z dodatnim wynikiem testu } \\
\text { NMówię"/ wadami wymowy } \\
\text { oraz dodatnim wynikiem testu } \\
\text { "Styszę" }\end{array}$ & $\begin{array}{c}\text { Procent } \\
\text { badanych } \\
\text { dzieci }\end{array}$ \\
\hline 77 & 8 & $47,06 \%$ \\
\hline
\end{tabular}

Powstała potrzeba weryfikacji otrzymanych rezultatów poprzez przeprowadzenie dodatkowego badania, mianowicie audiometrii tonalnej, by z jednej strony ograniczyć pole błędu (mając świadomość, że na przebieg testu przesiewowego mogły mieć wpływ czynniki zewnętrzne, takie jak: „rozkojarzenie”, dzwonek na przerwę itp.), z drugiej przekonać się, czy na wady wymowy u tej grupy dzieci mogły mieć wpływ pewne ubytki słuchu. Dodatkowo przebadano audiometrem również te dzieci, które uzyskały dodatni wynik wyłącznie w teście „Słyszę...”, zaś w teście „Mówię..." uzyskały rezultat zadawalający. Jest to grupa stanowiąca ponad 15\% spośród ogółu badanych.

Tabela 12. Liczba dzieci wyłącznie z dodatnim wynikiem testu „Styszę...”

\begin{tabular}{ccc}
\hline $\mathbf{N}$ & $\begin{array}{c}\text { Liczba badanych dzieci } \\
\text { z dodatnim wynikiem testu } \\
\text { „Styszę...” }\end{array}$ & $\begin{array}{c}\text { Procent } \\
\text { badanych } \\
\text { dzieci }\end{array}$ \\
\hline 77 & 12 & $15,58 \%$ \\
\hline
\end{tabular}

Po podziale na klasy rozkład tej grupy przedstawia się następująco:
Tabela 13. Zestawienie porównawcze liczby dzieci z dodatnim wynikiem testu „Słyszę...” w poszczególnych przedziałach wiekowych

\begin{tabular}{lccc}
\hline Klasa & $\begin{array}{c}\text { Liczba } \\
\text { badanych } \\
\text { ogółem }\end{array}$ & $\begin{array}{c}\text { Liczba badanych } \\
\text { dzieci } \\
\text { z dodatnim } \\
\text { wynikiem } \\
\text { testu „Styszę" }\end{array}$ & $\begin{array}{c}\text { Procent } \\
\text { badanych } \\
\text { dzieci }\end{array}$ \\
\hline Klasa I & 28 & 1 & $3,57 \%$ \\
\hline Klasa II & 24 & 6 & $25,00 \%$ \\
\hline Klasa III & 25 & 5 & $20,00 \%$ \\
\hline
\end{tabular}

\section{Szczegółowa analiza wyników uzyskanych w klasach I-III}

W dwóch klasach pierwszych wśród 10 osób posiadających wadę wymowy znajduje się 6 osób, które uzyskały dodatni wynik także $\mathrm{w}$ badaniu przesiewowym słuchu. Osoby te stanowią więc aż $3 / 5$ wszystkich pierwszoklasistów $\mathrm{z}$ wadami wymowy.

Tabela 14. Liczba dzieci z wadami wymowy oraz dodatnim wynikiem testu „Styszę...” wśród uczniów z klas I

\begin{tabular}{ccc}
\hline L & $\begin{array}{c}\text { Liczba badanych dzieci } \\
\text { z wadami wymowy oraz } \\
\text { dodatnim wynikiem testu } \\
\text { "Styszę" }\end{array}$ & $\begin{array}{c}\text { Procent } \\
\text { badanych } \\
\text { dzieci }\end{array}$ \\
\hline 10 & 6 & $60,00 \%$ \\
\hline
\end{tabular}

Tylko jedna osoba spośród 28 przebadanych w obu klasach miała dodatni wynik jedynie w badaniu przesiewowym słuchu.

Tabela 15. Liczba dzieci z dodatnim wynikiem wyłącznie testu „Słyszę...” wśród uczniów z klas I

\begin{tabular}{ccc}
\hline $\mathbf{N}$ & $\begin{array}{c}\text { Liczba badanych dzieci } \\
\text { z dodatnim wynikiem testu } \\
\text { „Styszę" }\end{array}$ & $\begin{array}{c}\text { Procent } \\
\text { badanych } \\
\text { dzieci }\end{array}$ \\
\hline 28 & 1 & $3,57 \%$ \\
\hline
\end{tabular}

W klasie drugiej sytuacja przedstawia się odmiennie. Na 6 dzieci posiadających wadę wymowy, tylko jedna osoba uzyskała dodatni wynik w obu przeprowadzanych testach przesiewowych.

Tabela 16. Liczba dzieci z wadami wymowy oraz dodatnim wynikiem testu „Styszę...” wśród uczniów z klasy II

\begin{tabular}{ccc}
\hline Liczba badanych dzieci & $\begin{array}{c}\text { Procent } \\
\text { z wadami wymowy oraz } \\
\text { dodatnim wynikiem testu } \\
\text { "Styszę" }\end{array}$ & $\begin{array}{c}\text { badanych } \\
\text { dzieci }\end{array}$ \\
\hline 6 & 1 & $16,67 \%$ \\
\hline
\end{tabular}


Jednak aż sześcioro dzieci uzyskało dodatni wynik w samym tylko teście „Słyszę..., co stanowi 1/4 wszystkich dzieci uczących się w tej klasie.

Tabela 17. Liczba dzieci z dodatnim wynikiem wyłącznie testu „Styszę...” wśród uczniów z klasy II

\begin{tabular}{ccc}
\hline $\mathbf{N}$ & $\begin{array}{c}\text { Liczba badanych dzieci } \\
\text { z dodatnim wynikiem testu } \\
\text { „Styszę" }\end{array}$ & $\begin{array}{c}\text { Procent } \\
\text { badanych } \\
\text { dzieci }\end{array}$ \\
\hline 24 & 6 & $25,00 \%$ \\
\hline
\end{tabular}

W dwóch klasach trzecich tylko jedna osoba posiada wadę wymowy oraz osiągnęła także dodatni wynik badania przesiewowego słuchu. Prócz tego 5 osób uzyskało dodatni wynik tylko w przesiewie słuchu, co stanowi $1 / 5$ wszystkich przebadanych trzecioklasistów.

Tabela 18. Liczba dzieci z wadami wymowy oraz dodatnim wynikiem testu „Styszę...” wśród uczniów z klas III

\begin{tabular}{ccc}
\hline $\mathbf{N}$ & $\begin{array}{c}\text { Liczba badanych dzieci } \\
\text { z dodatnim wynikiem testu } \\
\text { „Styszę" }\end{array}$ & $\begin{array}{c}\text { Procent } \\
\text { badanych } \\
\text { dzieci }\end{array}$ \\
\hline 25 & 5 & $20,00 \%$ \\
\hline
\end{tabular}

Podsumowując, tylko w klasach pierwszych widoczny jest duży odsetek badanych (60\%), mających dodatni wynik w obu testach przesiewowych. W klasach II oraz III utrzymywał się dość wysoki (rzędu 20-25\%) odsetek dzieci, które uzyskały dodatni wynik tylko w badaniu przesiewowym słuchu. Należy jednak zauważyć, że na każdym poziomie kształcenia wczesnoszkolnego (biorąc pod uwagę, że grupa pierwszoklasistów wynosi 28 osób, grupa drugoklasistów 24 osoby, zaś trzecioklasistów 25 osób, są więc liczebnie zbliżone) utrzymuje się stała liczba osób z dodatnim wynikiem badania przesiewowego słuchu, tj. 6-7 osób.

\section{Analiza audiogramów po przeprowadzeniu audiometrii tonalnej}

Jak już wspomniano przy ogólnej charakterystyce wyników badanej grupy, ponad 1/4 spośród wszystkich przebadanych dzieci uzyskała wynik dodatni w teście przesiewowym „Słyszę...”. Oprócz tego prawie połowa dzieci $\mathrm{z}$ dodatnim wynikiem badania przesiewowego słuchu uzyskała także dodatni wynik w teście przesiewowym mowy.

W toku badania ponownie przyjrzano się osiemnaściorgu spośród dwadzieściorga dzieci. Po analizie audiogramów wyniki podzielono na trzy grupy, poniekąd zgodnie ze stopniem ubytku słuchu, aczkolwiek jedynym kryterium nie była średnia wartość progu słyszenia, biorąc bowiem pod uwagę międzynarodowe normy wszystkie dzieci pod względem średniej wypadają pomyślnie. Najniższa średnia wartość progu słyszenia, jaką odnotowano, to $12 \mathrm{~dB}$ $\mathrm{w}$ prawym uchu, stwierdzone u dziewczynki z pierwszej klasy nauczania początkowego. Według Międzynarodowego Biura Audiofonologii o ubytku lekkiego stopnia można mówić przy progu wrażliwości słuchowej zawartej pomiędzy 21 a 40 dB. Z. M. Kurkowski (2000) postuluje obniżenie tej granicy tylko do $15 \mathrm{~dB}$, tak więc bezapelacyjnie jest to jeszcze norma. Po drugie, uwagę zwracają pewne zjawiska niespecyficzne: najczęściej kłopot sprawiały badanym skrajnie niskie częstotliwości nieujmowane przy obliczaniu średniego ubytku słuchu, zrodziła się więc potrzeba uwzględnienia przy klasyfikowaniu przede wszystkim częstotliwości, przy której dziecko osiągnęło najsłabszy wynik. Tak więc:

a) grupa I - reakcja na poziomie co najmniej $20 \mathrm{~dB}$ przy częstotliwości $250 \mathrm{~Hz}$ w jednym lub obojgu uszach (ośmioro dzieci);

b) grupa II - reakcja na poziomie co najmniej $15 \mathrm{~dB}$ przy częstotliwości $250 \mathrm{~Hz}$ w jednym lub obojgu uszach (pięcioro dzieci);

c) grupa III - reakcja na poziomie co najmniej $10 \mathrm{~dB}$ przy częstotliwości $250 \mathrm{~Hz}$ w jednym lub obojgu uszach (pięcioro dzieci).

W grupie I znajduje się większość dzieci, u których wykryto także wady wymowy (spośród ośmiorga posiadających dodatni wynik w obu testach przesiewowych, por. Tabela 11, w dniu badania obecnych było sześcioro dzieci, czworo zaś osiągnęło wyniki kwalifikujące do tej właśnie grupy). Przykładowo, zamieszczony na następnej stronie audiogram należy do dziecka nieprawidłowo realizującego /r/. Biorąc pod uwagę, że cechy akustyczne /r/ zawierają się w przedziale średnio $500-1600 \mathrm{~Hz}$ [Łobacz, 1996, s. 178] nie trudno zauważyć, że znaczne obniżenie występuje akurat w tym zakresie częstotliwości. Rycina 1 przedstawia wynik badania słuchu, na którym widać, że w lewym uchu reakcja na częstotliwość $250 \mathrm{~Hz}$ pojawiła się przy natężeniu $30 \mathrm{~dB}$, przy kolejnej badanej częstotliwości następuje poprawa w odbiorze dźwięku, by przy 1000 Hz znów opaść do $20 \mathrm{~dB}$. Można zatem przypuszczać, że nienormatywna wymowa $/ \mathrm{r} /$ jest spowodowana pewnym niedosłuchem, powodującym zaburzenia artykulacji głosek o niskich częstotliwościach formantowych - w związku $\mathrm{z}$ obniżeniem progu słyszalności dla tonów niskich, $\mathrm{w}$ tym wypadku właśnie drżącego /r/.

Podsumowując wyniki uzyskane w grupie I, można stwierdzić, że istnieje korelacja pomiędzy wadą wymowy a ubytkiem słuchu wśród dzieci. Tylko dwoje $\mathrm{z}$ ośmiorga badanych dzieci nie posiadało żadnych adnotacji dotyczących nienormatywnej wymowy. Istnieje tu wskazanie wnikliwej obserwacji ze względu na domniemanie, że podczas badania przesiewowego niektóre subtelne zmiany mogły uciec uwadze badającego. Troje dzieci $\mathrm{z}$ wadą drżącej /r/, biorąc pod uwagę statystyki fonetyczno-akustyczne, może nieprawidłowo realizować tę głoskę w związku z obniżeniem progu słyszenia w częstotliwościach odzwierciedlających właśnie jej cechy akustyczne. Podobnie jest $\mathrm{w}$ przypadku dziecka $\mathrm{z}$ mową bezdźwięczną, które najsłabsze wyniki osiąga przy częstotliwościach do $500 \mathrm{~Hz}$. Druga połowa badanych znajdująca się w grupie stworzonej na potrzeby niniejszej pracy, nie posiada jednoznacznych wskazań dotyczących wad wymowy. Tylko dwoje spośród czworga uzyskało adnotacje wypowiedzi niestarannych, na co również hipotetycznie mógłby mieć wpływ obniżony poziom słyszenia, rzutujący w omówionych zakresach częstotliwości na problemy np. z wychwyceniem dystynkcji dźwięczności. Ostatnia analizowana na podstawie audiogramów para dzieci, jak wspomniano wyżej, wymagałaby powtórnej obserwacji, możliwe 

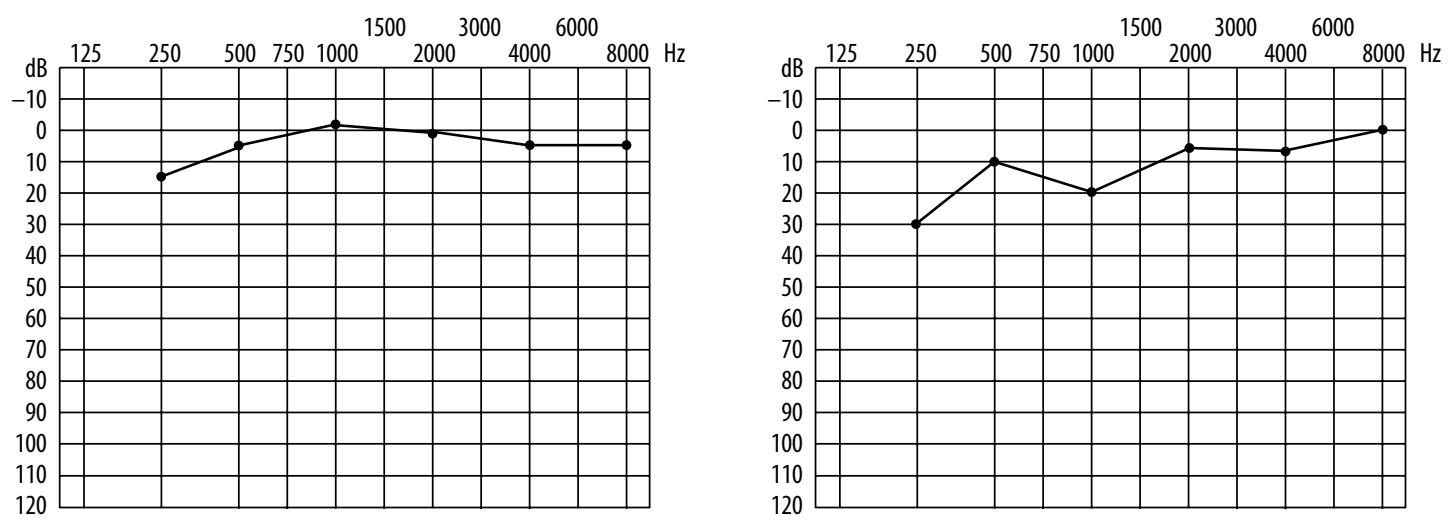

Rycina 1. Przykładowy audiogram dziecka z grupy I
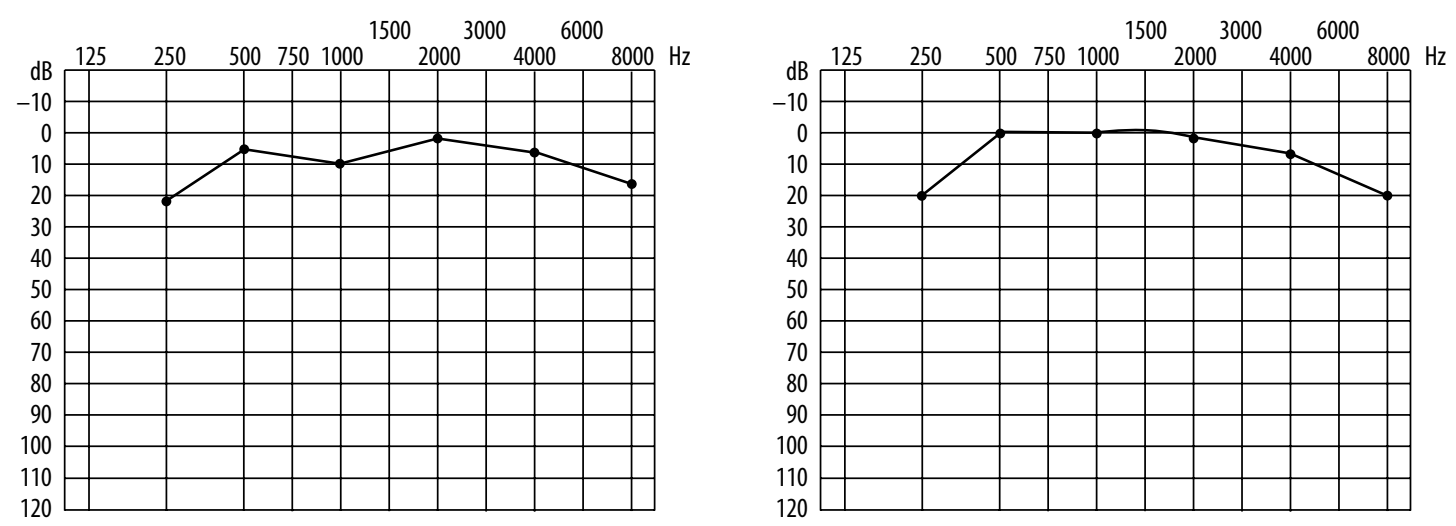

Rycina 2. Przykładowy audiogram dziecka z grupy II

bowiem jest przeoczenie pewnych rodzących się dopiero nieprawidłowości.

Do grupy II zakwalifikowano pięcioro dzieci (reakcja na poziomie co najmniej $15 \mathrm{~dB}$ przy częstotliwości $250 \mathrm{~Hz}$ w jednym lub obojgu uszach). Charakterystyczne jest, że zostały one zaklasyfikowane do badania audiometrycznego na podstawie wyłącznie dodatniego wyniku testu przesiewowego słuchu, co nie wiązało się z potrzebą korelacji z wadą wymowy, a raczej z próbą wychwycenia pewnych drobnych nieprawidłowości. Tak więc wszystkie dzieci znajdujące się w tej grupie osiągnęły słaby rezultat przy częstotliwości $250 \mathrm{~Hz}$. Nasuwa się tu skojarzenie z możliwością zaburzenia dystynkcji dźwięczności, biorąc pod uwagę najnowsze badania, które nie klasyfikują arbitralnie mowy bezdźwięcznej na zasadzie normy i patologii, a wskazują na wymowę: normatywną, bezdźwięczną, częściowo dźwięczną, częściowo bezdźwięczną. Byłoby to zatem pole do kolejnych, bardziej wnikliwych badań, gdyż na obecnym etapie można wyłącznie domniemywać o rodzących się nieprawidłowościach. Ponadto „wykorzystanie instrumentalnych technik pomiarowych w najnowszych badaniach dowodzi tego, że słuchowa ocena fonetycznej realizacji wypowiedzi często nie odpowiada realnym faktom. To samo zjawisko akustyczne może być odmiennie zinterpretowane nie tylko przez różnych słuchaczy, lecz także przez tego samego interpretatora" [Trochymiuk, 2008, s. 148]. Tak więc, tym bardziej

wskazaniem powinno być powtórne, bardziej wnikliwe przebadanie tej grupy dzieci.

W przykładowym audiogramie (por. Rycina 2) z tej właśnie grupy przedstawiono interesujące rezultaty należące do dziecka, któro znalazło się wśród badanych przez przypadek. Otóż wyniki badań przesiewowych słuchu wskazywały na brak konieczności bardziej wnikliwego badania i tylko pomyłka nauczycielki, która wskazała niewłaściwe dziecko, sprawiła, że znalazło się ono w polu zainteresowania. Choć można zauważyć, że i w tym przypadku średni wynik progu słyszenia w obojgu uszach nie budzi ogólnie zastrzeżeń; fakt, że dziecko to znalazło się wśród badanych przypadkowo pozwalałby przypuszczać, że wyniki będą o wiele lepsze niż u pozostałych dzieci. Sytuacja wygląda jednak wręcz odwrotnie; dziecko ma najsłabszy wynik wśród całej pięcioosobowej drugiej grupy. Pojawia się tu po raz kolejny postulat nietraktowania wyników PTA (ang. Pure Tone Audiometry) jako ostatecznych, lecz raczej jako wskazówkę wspierającą całościową diagnozę, tak by przy wątpliwościach bądź poważniejszych uszkodzeniach słuchu skorzystać z bardziej szczegółowych badań [Pruszewicz, 1992, s. 299]. Opisywana osoba uzyskała najsłabsze wyniki dla częstotliwości skrajnych - próg słyszenia w obu uszach przy częstotliwościach $250 \mathrm{~Hz}$ oraz $8000 \mathrm{~Hz}$ kształtuje się na poziomie $20 \mathrm{~dB}$ (co również nie ma przełożenia na średni ubytek słuchu, bowiem jak już niejednokrotnie wspominano, klasyczny wzór nie uwzględnia 

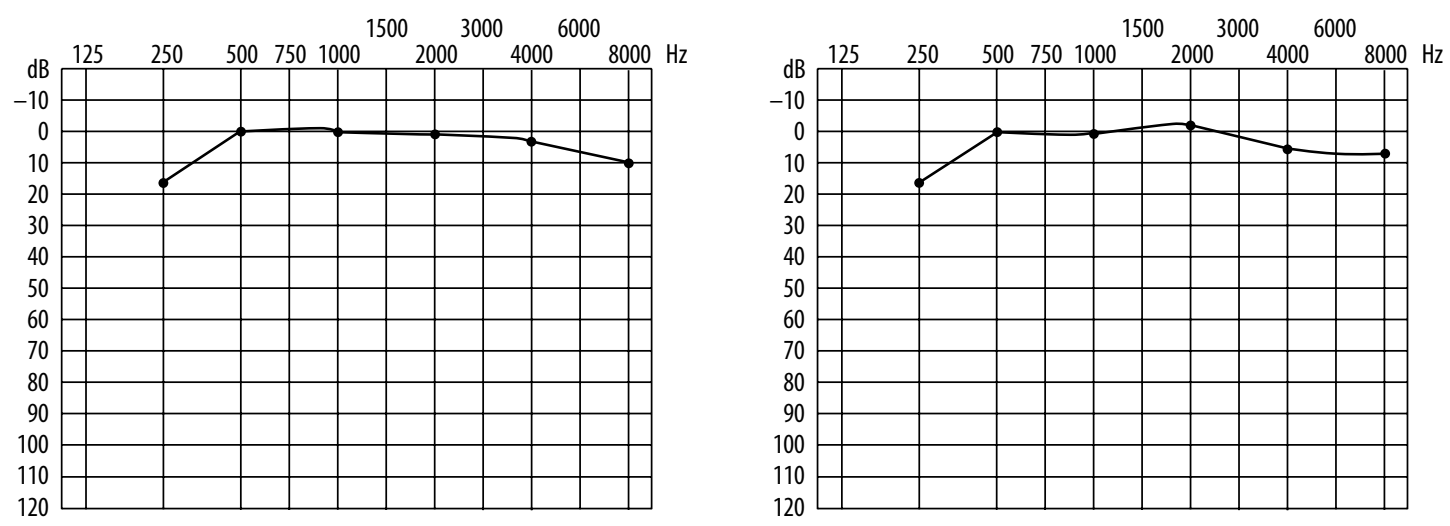

Rycina 3. Przykładowy audiogram dziecka z grupy III

skrajnych częstotliwości). Należałoby więc zweryfikować, czy dziecko prawidłowo realizuje kategorię dźwięczności oraz jak przedstawia się wymowa sybilantów.

Podsumowując wyniki dzieci z grupy II, trzeba stwierdzić, że choć nikt $\mathrm{z}$ badanych nie posiadał wady wymowy, to wyniki percepcji słuchowej nie są idealne. Należy zwrócić uwagę na fakt, że terenem badań była szkoła muzyczna, tak więc od tych dzieci powinno wymagać się ponadstandardowych rezultatów. Należałoby całą piątkę poddać wnikliwej obserwacji logopedycznej, by odnaleźć bądź wykluczyć ewentualne subtelne odchylenia i wady, które w przyszłości mogłyby się pogłębić.

W grupie III umieszczono pięcioro dzieci z najlepszym rezultatem (reakcja na poziomie co najmniej $10 \mathrm{~dB}$ przy częstotliwości $250 \mathrm{~Hz}$ w jednym lub obojgu uszach). Dwoje dzieci ma wadę wymowy. U osoby, której audiogram przedstawiono powyżej (por. Rycina 3), odnotowano zaburzenia w realizacji kategorii dźwięczności. Jednak sytuacja nie jest tak klarowna jak u osoby z grupy I, u której wykryto podobną wadę. W omawianym przypadku należałoby przeprowadzić dodatkowe testy pozwalające ustalić przyczynę zaburzeń realizacji opozycji \pm dźwięczna.

\section{Podsumowanie}

Analiza rezultatów uzyskanych w wyniku przeprowadzonych badań pozwala sformułować kilka istotnych wniosków, ważnych z punktu widzenia optymalizacji oddziaływań logopedycznych w zakresie diagnozowania i usuwania wad wymowy z oddziaływaniami audiologicznymi mającymi za zadanie wychwycenie i zminimalizowanie ewentualnych szkód spowodowanych ubytkiem słuchu. Jednakże, by odzwierciedlić sam proces analizy, niezbędne jest syntetyczne przedstawienie podstawowych wskaźników zgodnie z zasadą od szczegółu do ogółu.

1. Wśród przebadanych 77 dzieci, ponad $22 \%$ posiadało wadę wymowy (utożsamiono je $\mathrm{z}$ dodatnim wynikiem przeprowadzonego testu przesiewowego mowy). Z każdą kolejną, wyższą klasą, liczba wad zmniejszyła się z 35\% w klasie pierwszej do nieco ponad $4 \%$ w klasie trzeciej. Są to wyniki przewidywalne i w zasadzie mieszczące się w przedziale procentowym, prezentowanym przez różnych badaczy na przestrzeni ostatnich 30 lat.
2. Najliczniej reprezentowaną wadą na każdym poziomie wiekowym był rotacyzm. Ogólnie wykryto tę wadę u ponad 1/5 wszystkich przebadanych dzieci. Najwięcej u dzieci w klasie drugiej, gdzie była to aż co druga występująca wada. W klasie trzeciej tylko jedno dziecko posiadało wadę wymowy i także był to rotacyzm. Tak dużą liczbę dzieci z rotacyzmem można tłumaczyć trudnościami rozróżnialności percepcyjnej głosek kontrastujących głównie w wymiarze czasu; realizacja /r/ u dzieci w młodszym wieku szkolnym podlega ciągłemu doskonaleniu, tak więc dosyć długo nieustalone są reguły fonologiczne w systemie językowym dla tego wibrantu [por. Łobacz, 1996].

3. Kolejnymi według częstości występowania wadami były: połączenie rotacyzmu z sygmatyzmem (ogółem prawie $1 / 4$ wszystkich wad, przy porównaniu klas od 30\% w klasie I do niemal 17\% w klasie II); sygmatyzm, z identycznym rozkładem w grupie jak przy wcześniej wspomnianym połączeniu obu wad, oraz mowa bezdźwięczna: prawie $12 \%$ wszystkich wad wymowy (w klasie drugiej stanowi prawie $17 \%$, zaś w klasie pierwszej $10 \%$ wszystkich wad wymowy).

4. Ponad $25 \%$ wszystkich przebadanych dzieci uzyskało dodatni wynik w teście przesiewowym słuchu. Po sprawdzeniu, czy i w jakim stopniu pokrywają się osoby z obu testów przesiewowych, uzyskano rezultat prawie $50 \%$. Tak więc prawie co druga osoba $\mathrm{z}$ wadą wymowy uzyskała także dodatni wynik testu przesiewowego słuchu. $\mathrm{W}$ tym momencie zrodził się pomysł przeprowadzenia bardziej szczegółowego badania słuchu, które pomogłoby odpowiedzieć na pytanie, czy hipotetyczna wada słuchu koreluje $\mathrm{z}$ wadą wymowy.

5. Udało się powtórnie przebadać osiemnaścioro dzieci (siedemnaścioro $\mathrm{z}$ wyselekcjonowanej grupy dwadzieściorga dzieci, które uzyskały dodatni wynik w przesiewowym badaniu słuchu plus jedna osoba przypadkowo wysłana przez nauczycielkę).

6. Zaskakująca okazała się obniżona recepcja częstotliwości skrajnie niskich, stąd podzielono audiogramy na trzy grupy, w zależności od poziomu reakcji na częstotliwość $250 \mathrm{~Hz}$. Wyniki całościowe wszystkich dzieci zakwalifikowanych do II etapu (PTA) odzwierciedla Tabela 19.

W pierwszej, mającej najsłabsze wyniki, grupie (w związ$\mathrm{ku} \mathrm{z}$ tym, że kolejne grupy w zasadzie tylko uzupełniają analizę, w niniejszym podsumowaniu opisana zostanie 
Tabela 19. Średnia arytmetyczna ubytku słuchu w grupie badanej audiometrem tonalnym

\begin{tabular}{ccc}
\hline \multirow{2}{*}{$\begin{array}{c}\text { Częstotliwość } \\
\text { w Hz }\end{array}$} & \multicolumn{2}{c}{ Ucho-ubytek słuchu w dB } \\
\cline { 2 - 3 } & Prawe & Lewe \\
\hline 250 & 19,44 & 20,27 \\
\hline 500 & 8,33 & 6,94 \\
\hline 1000 & 2,77 & 1,94 \\
\hline 2000 & 1,66 & 3,05 \\
\hline 4000 & 4,44 & 5,83 \\
\hline 8000 & 4,72 & 6,11 \\
\hline
\end{tabular}

jedynie grupa najliczniejsza) znalazła się przeważająca liczba osób z wadami wymowy. Cechy akustyczne głosek porównywane na podstawie pracy Jassema (1966) pokryły się $\mathrm{w}$ zasadzie $\mathrm{z}$ miejscem najsłabszego wyniku dla danej osoby przedstawionego na audiogramie, co pozwoliło skorelować wadę wymowy z przyczyną, jaką mógł być w przeważającym stopniu minimalny niedosłuch. Co prawda żadna $z$ przebadanych osób nie osiągnęła średniego wyniku ubytku słuchu choćby w granicach $21 \mathrm{~dB}$, czyli lekkiego ubytku słuchu wg Międzynarodowego Biura Audiofonologii, lecz audiogramy całej przebadanej grupy można uznać za daleko niesatysfakcjonujące, biorąc pod uwagę, że są to dzieci kształcone do roli profesjonalnych muzyków.

Tabele średnich wartości fizjologicznego ubytku słuchu [cyt. za: Pruszewicz, 1992] zestawione ze średnimi wynikami ubytków słuchu analizowanej grupy badawczej wskazują dobitnie, że istnieje dość poważna luka w literaturze, a co za tym idzie w praktyce audiologicznej i logopedycznej, skazująca tzw. przypadki graniczne ${ }^{2}$ na brak jakiejkolwiek opieki terapeutycznej przez zaszeregowanie tych osób do grupy ludzi z całkowicie sprawnym słuchem. Prowadzić to może do stopniowych, progresywnych ubytków, które po kilku, kilkunastu latach będą wymagały protezowania.

Ostateczne i najważniejsze wnioski, które wypływają z niniejszego artykułu, koncentrują się zatem wokół postulatu

Tabela 20. Średnie wartości fizjologicznego ubytku słuchu (dB) u mężczyzn w zależności od wieku

\begin{tabular}{|c|c|c|c|c|c|c|c|c|c|c|c|c|}
\hline \multirow{2}{*}{$\begin{array}{c}\text { Częstotliwość } \\
\text { w Hz }\end{array}$} & \multicolumn{12}{|c|}{ Przedziat wieku w latach } \\
\hline & $25-29$ & $30-34$ & $35-39$ & $40-44$ & $45-49$ & $50-54$ & $55-59$ & $60-64$ & $65-69$ & $70-74$ & 75-79 & $80-84$ \\
\hline 250 & 0 & 0 & 1 & 2 & 3 & 4 & 6 & 8 & 10 & 13 & 16 & 19 \\
\hline 500 & 0 & 0 & 1 & 2 & 3 & 5 & 7 & 9 & 12 & 15 & 18 & 22 \\
\hline 1000 & 0 & 0 & 1 & 2 & 3 & 5 & 7 & 9 & 12 & 15 & 19 & 23 \\
\hline 2000 & 0 & 1 & 3 & 5 & 7 & 10 & 13 & 17 & 22 & 27 & 33 & 40 \\
\hline 3000 & 1 & 3 & 5 & 8 & 11 & 15 & 20 & 25 & 31 & 37 & 44 & 52 \\
\hline 4000 & 1 & 4 & 7 & 11 & 16 & 21 & 26 & 31 & 37 & 44 & 51 & 59 \\
\hline 6000 & 2 & 5 & 9 & 14 & 19 & 24 & 30 & 37 & 44 & 51 & 59 & 67 \\
\hline 8000 & 1 & 4 & 8 & 13 & 18 & 24 & 31 & 39 & 48 & 58 & 68 & 80 \\
\hline
\end{tabular}

Tabela 21. Średnie wartości fizjologicznego ubytku słuchu (dB) u kobiet w zależności od wieku

\begin{tabular}{|c|c|c|c|c|c|c|c|c|c|c|c|c|}
\hline \multirow{2}{*}{$\begin{array}{l}\text { Częstotliwość } \\
\text { w Hz }\end{array}$} & \multicolumn{12}{|c|}{ Przedział wieku w latach } \\
\hline & $25-29$ & $30-34$ & $35-39$ & $40-44$ & $45-49$ & $50-54$ & $55-59$ & $60-64$ & $65-69$ & 70-74 & 75-79 & $80-84$ \\
\hline 250 & 0 & 0 & 1 & 2 & 3 & 4 & 6 & 8 & 10 & 13 & 16 & 20 \\
\hline 500 & 0 & 1 & 2 & 3 & 4 & 5 & 7 & 9 & 11 & 14 & 17 & 21 \\
\hline 1000 & 0 & 1 & 2 & 3 & 4 & 6 & 8 & 10 & 12 & 15 & 18 & 22 \\
\hline 2000 & 0 & 1 & 3 & 4 & 6 & 8 & 11 & 14 & 17 & 21 & 25 & 29 \\
\hline 3000 & 0 & 1 & 3 & 5 & 8 & 11 & 14 & 17 & 21 & 26 & 31 & 36 \\
\hline 4000 & 1 & 2 & 4 & 7 & 10 & 13 & 17 & 21 & 26 & 31 & 37 & 44 \\
\hline 6000 & 1 & 3 & 6 & 9 & 13 & 17 & 22 & 27 & 33 & 39 & 46 & 53 \\
\hline 8000 & 1 & 2 & 5 & 8 & 12 & 16 & 22 & 29 & 37 & 46 & 57 & 69 \\
\hline
\end{tabular}

2. Za „przypadki graniczne” uznaje się osoby, u których średni ubytek słuchu mieści się w granicach 10-20 dB. 
bardziej obiektywnego, szczegółowego oraz indywidualnego traktowania każdego pacjenta.

Podsumowując przebieg przeprowadzonych badań, można założyć, że pierwotnie wytyczone cele zostały osiągnięte, a postawione pytania nie pozostały bez odpowiedzi. Choć uzyskane rezultaty nie napawają optymizmem, można mieć nadzieję, że dynamicznie rozwijające się dziedziny wiedzy jak logopedia i audiofonologia wzbogaca na tyle jakość postępowania diagnostycznego, że za jakiś czas opisany problem będzie choć częściowo nieaktualny. W tym upatruje się więc sensu badań przeprowadzonych w tym obszarze.

\section{Piśmiennictwo:}

1. Czyżewski A., Kostek B., Skarżyński H.: Technika komputerowa $w$ audiologii, foniatrii i logopedii. Warszawa, 2002

2. Emiluta-Rozya D., Mierzejewska H., Atys P.: Badania przesiewowe do wykrywania zaburzeń rozwoju mowy u dzieci dwu-, cztero- i sześcioletnich. Warszawa, 1995

3. Grabias S., Kurkowski Z.M., Woźniak T.: Logopedyczny test przesiewowy dla dzieci w wieku szkolnym. Lublin, 2002

4. Jastrzębowska G.: Stan i perspektywy opieki logopedycznej w Polsce (W:) Gałkowski T., Jastrzębowska G. (red.). Logopedia - pytania i odpowiedzi. Opole, 2003

5. Jassem W.: Podstawy fonetyki akustycznej. Warszawa, 1973

6. Jassem W.: Właściwości akustyczne mowy polskiej. (W:) Kutzner J. (red.). Sygnał mowy w telekomunikacji i cybernetyce. Warszawa, 1966

7. Krajna E.: 100-wyrazowy test artykulacyjny. Poznań, 1998

8. Kurkowski Z.M.: Audiogenne uwarunkowania zaburzeń mowy. Logopedia, 2000; 28
9. Kurkowski Z.M.: Kształtowanie się zdolności słuchowych a rozwój mowy. (W:) Grabias S. (red.). Zaburzenia mowy. Mowa teoria praktyka. Lublin, 2001

10. Kurkowski Z.M.: Mowa dzieci sześcioletnich z uszkodzonym narządem słuchu. (W:) Grabias S. (red.). Komunikacja językowa i jej zaburzenia, tom 13. Lublin, 1996

11. Kurkowski Z.M.: Rola kontroli słuchowej w procesie artykulacji. Logopedia, 2002; 31

12. Łobacz P.: Polska fonologia dziecięca. Warszawa, 1996

13. Pruszewicz A. (red.): Foniatria kliniczna. Warszawa, 1992

14. Skarżyński H., Czyżewski A., Senderski A.: Badania przesiewowe słuchu u dzieci i młodzieży w wieku szkolnym. I. Tester słuchu „Słyszę..... Audiofonologia, 2001; 20

15. Skarżyński H., Mueller-Malesińska M., Wojnarowska W.: Klasyfikacje zaburzeń słuchu. Audiofonologia, 1997; 10

16. Tarkowski Z.: Przesiewowy test logopedyczny. Lublin, 1992

17. Trochymiuk A.: Wymowa dzieci niesłyszących. Analiza audytywna i akustyczna. Lublin, 2008 